\title{
Aboriginal Land Rights Legislation in Australia
}

\author{
By Philip McNamara
}

In an article published recently in this journal, Professor Crawford discussed the work of the Australian Law Reform Commission pursuant to its reference on the recognition by the Australian legal system of Aboriginal customary law. ${ }^{1}$ In the course of his article, Professor Crawford referred briefly to the question of aboriginal land rights and to the legislation then in force pursuant to which grants of land in Australia have been made to aboriginals. ${ }^{2}$ The reader of that article will have learned that, for the aboriginal natives of Australia, occupation of their traditional lands was crucial to their spiritual well-being and to the preservation of their civilisation. For this reason, it is of the highest importance to those aboriginals still living within a tribal structure that they regain inalienably occupation of the tribal lands of which they were deprived either by government action or private ouster after the colonisation of Australia by the English Crown.

The various statutes now in force in Australia by means of which aborigines are presently able to claim land back from the Crown are known collectively as "aboriginal land rights legislation" and it is the scope, structure and legal effect of this legislation which will be the subject of this article.

In comparison with the approach adopted by the English colonisers of Africa, New Zealand, North America and India to the indigenous peoples of those places, the treatment meted out to the Australian aboriginals was particularly high-handed and inhumane. In 1788, when the English declared New South Wales to be a colony of the British empire, Australia, including van Dieman's Land (as Tasmania was then known) was occupied by some 300000 aboriginals. After colonisation, the indigenes were gradually displaced from their tribal lands by force of arms. Nevertheless, the colonial and imperial judiciary adopted and have persevered with the myth that the imperial occupation of Australia was a peacef ul settlement of previously unoccupied territory. ${ }^{3}$ Involuntarily, the aboriginals thus became subjects of the Crown of England. Worse, their legal systems were ousted by the common law of England. No recognition was afforded to aboriginal rules by which rights of occupation of land were created and regulated. Radical title to all land in Australia was taken to be vested in the Crown ${ }^{4}$ to the absolute

1 James Crawford, The Australian Law Reform Commission's Reference on the Recogition of Aboriginal Customary Law (1984) in: Verfassung und Recht in Ubersee, 17 No. 2, 133.

2 Id., 163-165.

3 Attorney-General (NSW) v. Brown (1847) 1 Legge 312; 2 SCR (NSW) (App) 30; Williams v AttorneyGeneral (NSW) (1913) 16 CLR 404; Cooper v Stuart (1889) 14 App. Cas. 286 (PC); Coe v Commonwealth (1979) 24 ALR 118.

4 A.C. Castles, An Australian Legal History, (Law Book Co., 1892), pp. 20-31 and chapter 18. 
exclusion of the previous indigenous owners. ${ }^{5}$ Of all the steps taken by the colonisers in their treatment of the aboriginals, the ouster of the indigenes from their tribal lands was the most dramatic in the curtailment of aboriginal civilisation as a viable system of laws, customs, rites and traditions.

The aboriginal populations in those areas of Australia settled by the arriving whites Tasmania, the eastern coast of the mainland and the Swan River basin in Western Australia were settled first - fell sharply. By about 1830 , the aboriginal population of Tasmania had fallen from its pre-colonialisation level of 4000 to about 250.6 On the mainland, the native population had fallen, by the same year, to about 60000 . After an enquiry by the House of Commons of England in 1837 had publicised this appalling side-effect of colonisation, ${ }^{7}$ some steps were taken to preserve the aboriginals' right to forage over land still owned by the Crown; and Crown leases to settlers for pastoral and agricultural purposes began to be made subject to the condition that the lessee permit aborigines to exercise their traditional hunting rights. ${ }^{8}$ In the nature of things, these conditions were not enforceable by the natives themselves. Further, in the settled areas on the eastern ans southern coasts and in Tasmania, where land was alienated largely in fee simple, no such protections were extended to aboriginals. In those areas, the natives either vanished or were herded onto reserves. By contrast, in the desert regions in the central, northern and north-western areas of Australia, regions unattractive to farmers and graziers until more recent times, a number of groups of aborigines remained physically free to preserve their tribal integrity. But, beginning at about the turn of the century, the States (as the former segregated Australian colonies became known upon federation in 1901) and the administrations of the federal territories implemented a coordinated policy of forcing those surviving bands of free aborigines onto reserves owned by the Crown. The reserves were variously managed by government departments or by Christian church organisations. A system of apartheid was thus brought about under legislative fiat. ${ }^{9}$ Reserves rarely coincided with traditional land boundaries. This

5 Milirrpum v Nabalco Pty. Ltd (1971) 17 FLR 141.

6 R. M. Berndt and C. H. Berndt, The World of the First A ustralians (1981), 520; C. D. Rowley, The Destruction of Aboriginal Society (ANU Press, 1970).

7 United Kingdom, House of Commons, Select Committee on Aborigines (British Settlements), P.P. (House of Commons) No. 425 (1837).

8 See e.g. Crown Lands Act 1979 (NT) s. 24 (2) and Land Act 1933 (WA) s. 106 (2) which preserve these conditions to the present day in those jurisdictions; the discussion in R. H. Bartlett, Aboriginal Land Claims at Common Law (1983) 15 Univ. of W.A L.Rev. 293, 342; Milirrpum, supra n. 5, 260-261; Australian Law Reform Commission Research Paper No 15: "Aboriginal Customary Law: The Recognition of Traditional Hunting, Fishing and Gathering Rights"; and Western Australia, The Aboriginal Land Inquiry (the Seaman Report), 1984, pars. 5.18-5.25.

9 Aborigines Protection Act 1909 (NSW); Aborigines Act 1911 (SA); Aboriginals Ordinance 1918 (NT); Cape Barren Island Reserve Act 1912 (Tas); Native Labourers Protection Act 1884 (Qld); Aboriginals Protection and Restriction of the Sale of Opium Act 1897 (Qld); Aboriginals Act 1905 (WA); Aborigines Act 1915 (Vic). There is a very penetrating discussion of the "protectionist" legislation enacted in Western Australia in chapter 12 of the Seaman Report, supra n.8. See, too, A. P. Elkin, The Australian Aborigines, (1964; rep. 1970) 362-381. 
segregationist era lasted until about $1950,{ }^{10}$ when it was displaced by the "assimilationist era ". During the segregationist era, aborigines were deprived by statute of the ordinary rights of personal freedom and property enjoyed by the rest of the Australian population.

At this stage, there were approximately 100000 aborigines in Australia. The largest aboriginal populations were found in the Northern Territory and Queensland. In those jurisdictions, there were approximately 19000 and 15000 non-urbanised aborigines respectively. In Western Australia there were some 13000 non-urbanised aborigines and, in South Australia, some 4000. There were only negligible numbers of non-urbanised aborigines in the other jurisdictions. ${ }^{11}$

In the 1960's, aboriginals in the Northern Territory (which was at that stage still under federal administration) and in South Australia began to agitate for their restoration to traditional lands. The federal government of the day prevaricated in a singularly cowardly and unprincipled fashion, choosing, as an alternative to direct government action, to grant funds to an aboriginal group to enable them to institute predictably futile court proceedings to ascertain whether their traditional land ownership system was recognised by the common law and capable of vindication within the legal framework of the Northern Territory. ${ }^{12}$

The governmental response in South Australia, New South Wales and Victoria was both more decisive and more favourable, although purely transitional in historical terms. In 1966, the South Australian Parliament enacted the Aboriginal Lands Trust Act. This Act authorised the State government to convey (in fee simple) Crown land in the State to a Land Trust which was required to hold the land for the benefit of aborigines. The Act gave neither tribes nor individuals a right to particular land. Substantial areas of land (some 485582 hectares) were vested in the Trust. Most of this land had previously been aboriginal reserves. Under the Act, the government had a discretion whether or not to transfer land to the Trust - the statute gave the aborigines no legal right to claim land. Nor did the Act guarantee that land would be allocated according to ancient patterns of land-holding. In practice, the trust leased areas of land to aboriginal groups free of any obligation as to its use. ${ }^{13}$

In Victoria, two parcels of land which had previously been reserves were vested in land trusts with a unit trust structure pursuant to the Aboriginal Lands Act 1970 (Vic). In New South Wales, virtually all reserves on Crown land were transferred between 1974 and 1980 to a lands trust set up under the Aborigines Act 1969 (N.S.W.).

The advance made by these three State statutes was that the aborigines who were permitted to occupy land vested in the trusts became free to do so without the restric-

10 Except in Queensland, where it was curtailed by federal legislation: Aboriginal and Torres Strait Islanders (Queensland Discriminatory Laws) Act 1975 (Cth).

11 Department of Aboriginal Affairs, Aboriginals in Australia Today, (1981) p. 4 Aboriginal Population.

12 Milirrpum, supra n. 5.

13 See South Australia, Reports on Aboriginal Lands Trust, PP 34/1977, 34/1978, 34/1979, 34/1980 and 34/1981 and N. Peterson (ed), Aboriginal Land rights - A Handbook (1981), 116. 
tions imposed by statute during the "reserves era" to which reference has already been made. The granted land was no longer required to be managed and administered by missionaries or bureaucrats. The aborigines remained subject to the ordinary law of the land but, at least in New South Wales, Victoria and South Australia, they ceased to be subject to discriminatory laws. They were, legally at least, free to choose whether to live separately from white society or within the mainstream communities.

\section{(1) The Federal Land Rights Legislation}

The first land rights statute in a strict sense was the federal Aboriginal Land Rights (Nothern Territory) Act 1976. This Act which, as its name implies, operates only in the Northern Territory - still under federal administration when the statute was enacted created four means by which land in the Territory might be acquired by descent groups of aborigines. As an administrative matter, the Act requires that land trusts be formed to act as land-holding entities for the intended aboriginal occupants. ${ }^{14}$ The land trusts are created in relation to fixed parcels of land by administrative action on the part of the responsible Minister. Each land trust takes land for the benefit of a single decent group. The land trusts are managed by the aboriginal occupants under the supervision of the regional Land Council. ${ }^{15}$

The four means of acquisition referred to in the last paragraph are as follows. First, be force of the Act itself, ownership of some twenty distinct regions was required to be vested in land trusts. ${ }^{16}$ Secondly, land trusts are authorised to purchase title to land, freehold and leasehold, on the open market; ${ }^{17}$ utilising receipts from mining royalties, aboriginal groups have been buying significant numbers of pastoral leasehold interests from white farmers and then seeking the conversion of the leasehold into inalienable title under the federal Act. ${ }^{18}$ Thirdly, the federal Minister in charge of the Act is required by the Act to convey to land trusts certain described parcels of land (which were, in 1976, affected by interests held by non-aboriginals), to be held in escrow until those subsisting interests terminate or are surrendered. ${ }^{19}$ Finally, the Act authorises descent groups of aboriginals to apply for the grant, to a land trust yet to be constituted on their behalf, of "unalienated Crown land" in the Territory.

The foreign reader will need some explanation of this last means of acquisition. The Act creates the office of Aboriginal Land Commissioner (sec. 49). A group of aboriginals

14 Sec. 4.

15 Sec. 5 .

16 Sec. $10(1)$.

17 Sec. 4(3)(c).

18 Contrast "Seven Years On" Report by Mr Justice Toohey to the Minister for Aboriginal Affairs on the Aboriginal Land Rights (Northern Territory) Act 1976 and Related Matters, ("the Toohey Report"), (AGPS, 1984) pars. 214-226.

19 Sec. $10(2)$. 
who claim to have, or to have had, ownership in accordance with aboriginal tradition of a parcel of unalienated Crown land in the Territory may lodge with the Commissioner an application for a recommendation that the parcel of land be granted to the group. The Commissioner is then required to conduct an administrative inquiry the purpose of which is to enable the Commissioner to ascertain whether the applicants, or some of them, are entitled to the land claimed, by aboriginal tradition. If the Commissioner is so satisfied, it is his duty to report his findings to the responsible Minister and to recommend to the federal Minister that a land grant be made to a land trust for the benefit of the successful applicants in respect of that land covered by the claim which is proved traditionally to belong to the successful applicants (sec. 50). The Minister is not bound to act on the recommendation of the Commissioner. ${ }^{20} \mathrm{~A}$ large number of land claims have been made under the Act. Only one has been totally unsuccessful. The Minister has never failed to act on a recommendation of the Commissioner favourable to the applicants. There is no time limit within which applications may be lodged by groups of aborigines.

On land being vested in a land trust by the Minister, it is, in general, inalienable - this reflecting the fact that, by aboriginal tradition, land was owned in community and could not be disposed of either by individual aboriginals or by the tribe as a whole - although leases to aborigines and leases for public purposes are permitted. ${ }^{21}$ By the same token, land so vested cannot be resumed or compulsorily acquired by the government of the Northern Territory (sec. 67). (Since 1979, the Northern Territory has been a semy-autonomous political entity; its conservative government has been and will probably remain hostile to the federal land rights laws; thus, the protections conferred on aboriginal lands by the federal statute are very important to the aborigines).

Upon land being vested in a lands trust, it may be occupied and used by aborigines in accordance with aboriginal tradition (sec. 71). If permitted by tradition, the land may be occupied temporarily and foraged over even by aborigines whose connexion with the land was not sufficiently strong to have enabled them to have successfully prosecuted a land claim in their own rights. The land cannot be entered or used except in accordance with traditional practices, except as specifically required or permitted by or consistently with the federal Act. The effect of these restrictions has been the almost total exclusion of tourists, non-aboriginal farmers and mining operators from land vested in land trusts. The concept of the land trusts is, of course, alien to aboriginal tradition. As a practical matter, aborigines have had to acquiesce in the vesting of their traditional lands in statutory entities, rather than in tribes or sub-collectives, to enable aboriginal land ownership to exist compatibly with the scheme of registration of title to land in the Territoryand elsewhere in Australia for that matter. The legislation declares each land trust to be a body corporate (sec. 4[3]) so that each trust is, in the eyes of the law, distinct

20 Sec. 11, as to which see the decision of the High Court in Re Toohey; Ex Parte Meneling Station (1982) 57 ALJR 59.

21 Sec. 19(2). 
from those for whose benefit it holds the land. Each land trust is managed by a committee of at least three aboriginals living in the area of the land held by the trust (sec. 7[6]). The committee is appointed for a term not exceeding three years by the federal Minister from among persons nominated by the regional Aboriginal Land Council (sec. 7[2], [3]). The land trust is required to exercise its statutory powers for the benefit of the successful applicant group and in accordance with directions from the regional Land Council (sec. 5). The land trusts are purely land-holding and land-management entities. They are not permitted to receive moneys and their financial affairs are managed on their behalf by the regional Land Council (secs. 6, 26, 27).

The administrative entities created by the Act do not sit comfortably with traditional aboriginal modes of decision-making. Historically, decisions within aboriginal communities were made by the tribal elders who had risen to the status of ceremonial leaders. The members of the Land Councils, who collectively now wield power on behalf of aboriginal communities in their dealings with the outside world, are elected by the general body of aboriginals within the region concerned (sec. 29). Those elections are not required to reflect traditional hierarchical arrangements and in practice they do not do so, with the consequence that important decisions affecting elders of high ceremonial status may be made by Land Council members of low or no ceremonial status. To give one example: it is the Land Council which decides whether or not access to aboriginal lands may be had by outsiders for, e. G., mining purposes and whether a road may be opened over aboriginal land (secs. 41, 68). Now, in making decisions of that kind, the Land Council is under a statutory obligation, inter alia: "(a) to ascertain and express the wishes and opinions of Aboriginals living in the area of the Land Council as to the management of Aboriginal land in that area ...

(b) to protect the interests of traditional Aboriginal owners of, and other Aboriginals interested in Aboriginal land in the area of the Council ...

(c) to consult with traditional Aboriginal owners of, and other Aboriginals interested in, Aboriginal land in the area of the Land Council with respect to any proposal relating to the use of that land"... (sec. 23[1]).

But the Act does not guarantee that the views of the traditional decision-makers will prevail. Nor does the Act distinguish between decisions affecting ritual or sacred matters and mundane matters. This has given rise to the suggestion that the Land councils be made bicameral, the one house devoted to mundane affairs and the other concerned with sacred or religious matters. ${ }^{22}$

22 This suggestion is discussed in the Toohey Report, supra n. 18, pars. 318-323. See also S. McGill, "European Systems Don't Meet aboriginal Needs", (1980) 5 L. S. Bull. 269; and P. Toyne and D. Vachon, Growing $U p$ The Country (Penguin, 1984) 62-64. 


\section{(2) The Current South Australian Legislation}

The novel feature of the federal legislation dealt with in the preceding section of this article was its creation of a scheme enabling claims for land to be made by groups of aboriginals. That feature is not present in the South Australian land rights legislation. All land granted so far to aboriginal groups in South Australia has been granted by the executive arm of government pursuant to direct legislative mandate. In other words, it has been the State Parliament, rather than an administrative tribunal, which has determined whether land is to be granted to aboriginal groups and the very boundaries of that land. Parliament has not considered itself bound by traditional boundaries.

Like the federal legislation, the South Australian legislation provides for the vesting of land in bodies corporate which are to act as land-holding entities. These are the Anague Pitjantjatjaraku, constituted under the Pitjantjatjara Land Rights Act 1981 and the Maralinga Tjarutja, constituted under the Maralinga Tjarutja Land Rights Act 1984. Some $100,000 \mathrm{~km} 2$ of land in the north-western region of South Australia (straddling the Great Victoria desert) have been vested in the former body. An area of approximately $76,000 \mathrm{~km} 2$ of land will be vested in the latter body; this land lies in the southwestern corner of the State and will vest after the Royal Commission appointed to inquire into the Maralinga Atom bomb tests has reported. The statutes are virtually in the same terms and deem members of named tribes to be members of the bodies corporate which they create. Aboriginals who are not members of those bodies corporate have no right to enter the land vested under the Act. Whether further areas of land are granted to aboriginals is quintessentially a political matter.

The statutory bodies corporate are requiered to "ascertain the wishes and opinions of traditional owners in relation to the management, use and control of the [vested] lands and to seek, where practicable, to give effect to those wishes. ${ }^{23}$ The bodies corporate are each managed by Councils, in which are vested the powers, functions and affairs of the body corporate. The Maralinga Tjarut ja council comprises all persons who are, for the time being, leaders of the traditional owners of the lands. ${ }^{25}$ In making its decisions, the Councils are required to consult with the traditional owners and to act with regard to the customs of the traditional owners. ${ }^{24}$ To this extent, the management provisions of the South Australian legislation are an improvement to the federal Act and, at least on their face, are calculated to preserve the prestige and ceremonial status of the tribal elders.

23 PLR Act sec. 6(1)(a); MTLR Act sec. 5(1)(a).

24 MTLR Act sec. 6(1). The executive organ of the Anangu Pitjant jatjaraku is known as the Executive Board and is elected at general meetings of the body corporate at which all members may vote: PLR Act secs. 8, 9.

PLR Act sec. 7; MTLR Act sec. 8. 


\section{(3) The New South Wales Legislation}

The New South Wales Aboriginal Land Rights Act 1983 is similar to the federal legislation in that it creates a claims procedure by which aboriginal groups may gain title to land. But in one important respect, the New South Wales statute differs federal Act. Under the federal statute, the claimant group must demonstrate that it is the traditional owner of the land claimed (secs. 4,50). Such a requirement would, in New South Wales, render the claims procedure futile, because there are virtually no extant tribal groups; New South Wales was almost completely settled by whites by the turn of the century, with the result that those aborigines who survived the onslaught of the English occupation were evicted from their lands several generations ago.

For this reason, in New South Wales, claims for grants of land may be made only by the State Aboriginal Council or by a local Aboriginal Land Council. It is not required that claims be lodged on behalf of descent groups or on behalf of groups having a tribal identity. Claims may be lodged in respect of what the Act calls "claimable Crown Land". In effect, this embraces Crown land which is neither occupied nor needed for an essential public purpose (sec. 36). The application is made to a State Minister, not to an independent statutory tribunal. If the Minister is satisfied that the land claimed meets the statutory criteria of "claimable Crown land", he is bound to accede to the application: there is no residual discretion to ref use a grant and there are no other facts of which the Minister is required to be satisfied. Any decision by the Minister that the land claimed is not "claimable" is appealable to the Land and Environment Court (sec. 36). As is the case under the federal Act, there is no time limit on claims.

There are three other methods by which aboriginals in New South Wales may acquire land under the Act. First, aboriginal councils may acquire land by voluntary purchase (sec. 38). Secondly, the Act provides for the vesting in Aboriginal Land Councils of lands formerly dedicated as reserves under the Aborigines Act 1969 (sec. 35). Thirdly and this feature is without parallel elsewhere in Australia - with the consent of and through the agency of the State government, aboriginal councils may procure the compulsory acquisition of any land, whether privately owned or still managed by the Crown: but in the event of a compulsory acquisition of privately occupied land, the aboriginal purchasers are required to pay compensation (sec. 39). Funds to enable compensation to be paid are to be derived from amounts hypothecated by the State, equivalent to $7.5 \%$ of annual land taxes collected before 1998 .

Once land has become vested in an Aboriginal Land Council, it becomes inalienable except to the extent permitted by the Act and cannot be resumed or compulsorily acquired by the State (secs. 40,42 ). 


\section{(4) Other Australian Jurisdictions}

There is no land rights legislation in force or in prospect in Queensland and in Tasmania, the present State governments being implacably opposed to the concept of ownership of land by aboriginal groups in perpetuity. There is no land rights legislation in force in the Australian Capital Territory (the seat of federal Government) because there are no non-urban aborigines in the Territory, except at the coastal settlement of Jervis Bay, where an aboriginal community has been granted a lease of Crown land. ${ }^{26}$ In Victoria and in Western Australia, bills for Land Rights Acts have been tabled in the State legislatures but have met with obstruction form the conservative majorities in the upper houses of Parliament. ${ }^{27}$

The present federal government proposed to introduce into Parliament a bill for a national land rights Act. The intended Act would have been of primary effect in those jurisdictions, referred to above, where there no land rights legislation is contemplated by the State government. However, the proposed national Act would also have operated in jurisdictions where State Acts are in force or are contemplated (i.e. W.A. and Victoria), to the extent that the State Act conferred on aborigines rights which were less extensive than those to be created by the federal law, which would have been in substantially the same form and to substantially the same effect as the federal Act now operating in the Northern Territory. This being the case, and given that the State governments in the land rights States are of the same political persuasion as the federal government, the intended federal Act is doomed to failure except in Queensland and Tasmania. All the labour State governments protested against the proposed federal law on the ground that it was not appropriate in their respective jurisdictions.

Under aboriginal tradition, the right (or, more strictly, the obligation) of an aboriginal group to occupy a particular area of land was largely exclusive. Boundaries were fixed with more or less certainty and were, on the whole, respected by other groups. ${ }^{28}$ Acknowledging this, the land rights legislation does two things. First, it confers rights of occupancy and use of aboriginal lands by reference to aboriginal tradition..$^{29}$ Secondly, it prohibits entry onto aboriginal lands by persons who, according to aboriginal tradition, have no right of use or occupation of the land subject to limited exceptions created by statute. It is this prohibition which excludes non-aboriginals from entering aboriginal

26 See Philip McNamara, Mineral Resources in Lands Owned by Australian Aborigines (1985) 00 J. of Energy Law and Policy 000, n. 9.

27 See McNamara, op.cit., supra n.26, pp 000-000; the Seaman Report, chapters 7 and 9 and the Aboriginal Land Bill 1985 (WA) and the Acts Amendment (Aboriginal Land) Bill 1985 (WA). For political reasons, the government of Western Australia rejected the draft legislation proposed in the Seaman Report and tabled compromise legislation. Even that legislation has been opposed by the conservative parties.

28 See Milirrpum, supra n.5, 179 and the Seaman Report, supra n. 8, chapters 3 and 12.

29 See s. 71 of the Commonwealth Act; PLR Act s.18; MTLR Act s. 17. The proposition on the text does not apply to the N.S.W. legislation, under which aborigines are expected to derive their right to occupy a particular parcel of land by way of a lease from the relevant Local Aboriginal Land Council: s. 40 (4). 
land, except with permission or except for the purpose of discharging some public or statutory function. In general, then, aboriginal lands become unavailable for occupation by non-aboriginals, individually or in settlements, and may lawfully be exploited for farming or mining purposes only by the aboriginal occupants or (by outsiders) with their permission. Recognising the dual facts that most lands granted to aboriginals are in remote areas and that the mining industry is currently of great importance to the Australian economy, special regimes are created by the legislation the effect of which is to permit mining operations to be conducted on aboriginal lands without the permission of the appropriate aboriginal council in defined circumstances. ${ }^{31}$

\section{(5) The Way Ahead}

Since 1965, the legal treatment of aborigines in Australia, at an abstract level, has improved markedly. This improvement has been an indirect consequence of an amendment, in 1967, to the federal Constitution which repealed a prohibition against federal legislation aimed at peoples of the aboriginal race. The discriminatory legislation of previous decades has vanished everywhere except in Queensland, where its demise will be brought about sooner or later by federal legislation implementing international human rights covenants and conventions. Equally, aborigines everywhere in Australia now have the right to vote. They no longer live in conditions of legal apartheid. At law, they enjoy the same rights and freedoms as other citizens.

Yet a sizeable proportion of aboriginal people express reasoned dissatisfaction not only with the economic and social conditions of aborigines but also with the legal status quo. ${ }^{32}$ They seek the recognition of aboriginal customary law by the dominant system and the repeal of non-traditional laws still operative on aboriginal lands. Aboriginal groups have lodged complaints about conditions in Australia to various United Nations Committees $^{33}$ and to the Sub-Commission on the Prevention of Discrimination and Protection of Minorities. ${ }^{34}$ Certain aboriginals wish to see aboriginal lands become sovereign or semi-sovereign entities. ${ }^{35}$

Given the known or suspected reserves of minerals in or near lands granted to aborigi-

30 See s. 70 of the Commonwealth Act; PLR Act s. 19; MTLR Act s. 18; and s. 45 (4) of the Aboriginal Rights Act 1983 (NSW), which prohibits only the unconsented entry onto aboriginal lands for mining purposes.

31 See Part IV of the Federal Act; PLR Act Part III Div. 3; MTLR Act Part III Div 4; as to NSW, where the position in relation to exploitation of minerals is peculiar, see Part VII of that State's Act.

32 See e.g. Gumbert, Neither Justice Nor Reason (Univ. of Qld. Press, 1984), pp. 24-25.

33 See M. Langton, Aboriginal Land rights in Australia: Background Paper, Draft Survey and Recommendations presented to World Congress of Indigenous Peoples, North Queensland Messagestick, 1981, vol. 6 (2), pp. 8-9.

34 See G. Nettheim, ed., Human Rights for Aboriginal People in the 1980's (1983, Legal Books Ltd.), 21, 28; S. Harris, It's Coming Yet (Griffin Press, 1979), pp. 26-29.

35 See the discussion in M. Barker, Aborigines, Natural Resources and the Law, (1983) 15 Univ. of W.A.L. Rev. 245, 246-257. 
nals, it is to be doubted that these claims to legal and political sovereignty will ever succeed. It is unlikely that aboriginals will, in the foreseeable future, gain any greater powers to control access to their lands than they enjoy at present. They may obtain freedom from planning and environment protection legislation, from taxation and from the general marriage and divorce legislation. Their claims to live exclusively under customary law may prevail. But it is predictable that their claims to control their lands as sovereign peoples will fail.

If this be correct, then it becomes all the more important that aborigines have the legal power to protect sites sacred to them, being sites that do not lie on aboriginal lands. These sites are at risk of destruction or despoliation, deliberately or inadvertently, whenever an area of land containing a sacred site is proposed to undergo a change of use. The legislation presently in force in Australia intended to protect sites of religious or ritualistic significance to aborigines has been treated elsewhere. ${ }^{36}$ Aborigines have a legitimate claim to have that legislation amended so as to give them greater control over the nomination of sites for protection and the measures to be adopted for their protection. 